BART'TER'S SYNDROME (BS) INDUCED BY MILK-FREE SOY

7 ISOLATE INFANT FORMULA (NEO-MULLSOY). Salcedo, J.R. Department of Nephrology. Children's Hospital Nat'l Medical Center, George Washington University Schuol of Medicine, Washington, D.C.

Barter's syndrome is characterized by hypokalemic metabulic alkalosis, hyperreninemia, aldosteronism, normotension and hyperplasia of the juxtaglomerular apparatus (JGA). A retruspective analysis of four infants, ages 5 to 8 months $(6 \pm 1.2 \mathrm{~m}$.) who were fed milk free soy isolate formula $(N)$ for $S \pm 1.2$ months was under taken. All the patients sought medical attention for failure to thrive (FTT) and all of them had signs and symptoms undistinguishable of BS, namely severe metabolic acidosis ( $\mathrm{pH} \mathrm{7.62 \pm 0.6),} \mathrm{HCO} 3$ $40 \pm 3(\mathrm{BE}+17 \pm 3)$, Hypuchloremia (Cl $72 \pm 9 \mathrm{mEq} / 1$ Hypokalemia $(\mathrm{K} 2.8+0.3 \mathrm{mEq} / 1$.) Hypercalcemia was observed in 2 patiencs. One patient had microscopic hematuria; 3 patients had renin levels in excess of $300 \mathrm{ng} / \mathrm{ml} / \mathrm{hr}$ associated with high aldosterone levels in the presence of normotension. Initial urinary electrolytes showed cont inuous moderate $\mathrm{K}$ and $\mathrm{Na}$, with minimal chloride loss. Furmula change and intravenous $\mathrm{NaCl}$ lead to rapid correction of abnormal laboratory results. The severe metabolic abnormalities observed in these infants cannot be explained solely by the low chloride levels in this formula, nor the high renin and aldosterone or the microscopic hematuria. Prostaglandin-like substances, or precursors of them should be taken into consideratin. Prospective studies of this occurrence may help to develop an animal model to further understanding of BS.

\section{URINARY TRACT INFECTION}

SHORT TERM TREHTIVIET OF CHILDHOOD UTI.

8 Helin, I. Dept of Peoiatrics, University of Lund, General Hospital, Malmö, Sweden.

In the treatment of UTI in children there is no welldocumented guideline about the duration of therapy. This study vas undertaken to investigate whether a 3days course of trimethoprim/sulphadiazine (TMP/SDZ) was effective in eradicating non-febrile UTIs in chlldren 1 - 15 years of age.

Forty children were randomly assigned a 3- or 10-days treatment with $\mathrm{TMP} / \mathrm{SDZ}$, administered twice daily in a dose of $16 / 4 \mathrm{mg}$ per $\mathrm{kg}$ bw per day. They all had symptomatic lower UTIs with significant bacteriuria. Temperature below $38^{\circ} \mathrm{C}$ and ESK below $10 \mathrm{~mm}$ in the first hour excluded the existence of an upper UTI.

Results: All children were abacteriuric at control one to three days after the cessation of therapy. out of 17 children on three days of therapy, infection recurred in two, two months after the index infection. Out of 23 pationts treated for 10 days, infection recurred also in two patients, two and five monthis after the index infection.

It is concluded from this study that in children with an acute lower UTI, treatment with TMP/SOZ for three days is effective in eradicating the bacteria and that the treatment does not increase the risk of oarly recurrence as compareo to treatment for 10 deys.

9 The pk antigen as receptor for pyelonephritic E.coli

Källenius, G., Möllby, R., Lundblad, A., Winberg, J. Department of Pediatrics, Karolinska Hospital, Karolinska Institute, Stockholm, Department of Bacteriology, National Bacteriological Laboratory, Stockholm and Department of Clinical Chemistry, University Hospital, Lund, Sweden.

The specific D-mannose resistant agglutination of human erythrocytes (MRHAhur) observed in uropathogenic E.coll strains was investigated. 14 consecutive pyeIonephritic E.coli strains were studied. All agglutinated human erythrocytes irrespective of their ABO or Lewis bloodgrouns. Neither was the HA affected by the content of $\mathrm{H}$ or $\mathrm{I}$ antigens on the erythrocytes. The agglutination was related to the $\mathrm{p}$ bloodgroun system. 13 of 14 strains agglutinated $P$ erythrocytes with the $\mathrm{pk}$ antigen but failed to agglutinate those lacking the common $\mathrm{F}^{\mathrm{k}}$ antigen (trihexosyl ceramide). The : $\mathrm{RHA}$ hum was inhibited by the trinexosyl oligosacharide but not by a large range of other olioosacharides. It is coniludec that the trihexosyl oligosacharide is the erythrocyte receptor of these E.coli strains. The :IRHAhum is paralleled with the ability of pyelonephritic E.coll strains to adhere to human perlurethral cells. mine receptor(s) on the surface of urinary tract enithelium may be the same as on the $P$ erythrocytes.
AGGLUTINATION OF HUMAN ERYTHROCYTES - A "RISK TEST"

10 FOR ESCHERICHIA COL I CAUSING UTI

Hagberg,L., Svanborg Edén,C. from the group on Host-Parasite interaction in UTI. Departments of Clinical Immunology and Pediatrics, University of Göteborg, Göteborg, Sweden.

Capacity to attach to urinary tract epithelium is a virulence factor in E.coli causing UTI (1). The aim of the present study was to correlate ability to attach to human urinary tract epithelium and to agglutinate erythrocytes from various species, thus indirectly clearifying the bacterial surface structures, pili, involved in attachment.

Methods: About 450 E.coli strains isolated from girls with acute pyeTonephritis, acute cystitis, asymptomatic bacteriuria and from the stools of healthy children were tested for capacity to attach to human urinary tract epithelial cells (2) and to agglut inate human, guinea pig and horse erythrocytes and yeast cells (3)

Results: Almost 100 per cent correlation was found between adhesive capacity and mannose-resistant agglutination of human erythrocytes. Mannose sensitive agglutination of guinea pig erythrocytes gave no such correlation.

Conclusion: Agglutination of human erythrocytes by E.coli may be a simpte risk test for urinary isolates.

References: (1) Svanborg Eden et al. Lancet II:490,1976, (2) Svanborg Edén et al. Infect. Immun. 18:767,1977, (3) Korhonen and Svanborg Edên, submitted for publ.

DFFERENTIATION BETWEEN UPPER AND LOWER URINARY TRACT INFECTION IN CHILDREN: A COMPARATIVE STUDY. Koegel,R.R.,Schopfer,K.Children's Hospital and Institute of Medical Microbiology, Section of Immunology, $9000 \mathrm{St}$ Gallen, Switzerland.

In order to differentiate lower from upper urinary tract infection (UTI) we have studied 40 children with clinical, haematological and bacteriological findings suggestive of UTI. The methods used included quantitative measurement of $\mathrm{C}$ reactive protein (CYP), erythrocyte sedimentation rate (ESR) and antibody coating of urinary bacteria (ACB) using a polyvalent FITC-labelled antiserum. 6 out of 8 children presenting with fever, back pain and leucocytosis had $\mathrm{Cr}$ P values $>2.0 \mathrm{mg} / 100 \mathrm{ml}$ and elevated ESR. In one child ESR only was elevated, in another child only CrP was above normal. ACB was demonstrated in the urinary sediment of one patient. In the remaining $32 \mathrm{children} \mathrm{Cr} P$ was $\leqslant 2.0 \mathrm{mg} / 100 \mathrm{ml}$ and ESR was elevated in 12 patients. These children were considered as having lower UTI by clinical and haematological findings. ACB were found in 3 patients with lower UTI. Antibiotic treatment of the patients with suggested upper UTI resulted in normalisation of CrP and ESR as well as of the clinical condition after 10 days. These results suggest that elevated ESR and CrP are indicative of upper UTI and should be treated. ACB was of no value in our study to differentiate upper from lower UTI.
SUBNORMAL LEVELS OF TAMM-HORSFALL ANTIBODIES IN CHILD-

12 REN WITH PREVIOUS UTI AND RENAL DAMAGE Jodal $U$, Fasth $A$, Hellström $M_{2}$, Jacobsson $B$ Dept of Pediatrics, University of Göteborg, East Hospital, S-416 85 Göteborg. Sweden.

Introduction: Identification of patients with renal damage after UTI with a simple test would be of value in pediatric practice. In previous studies a significant increase of Tamm-Horsfall (TH) antibodies was found in acute pyelonephritis, especially in children with vesico-ureteric reflux. In contrast patients with renal scarring and no recent UTI had low levels of IgG TH antibodies (Fasth et al. J Pediatr 95:54, 1979). This is of special interest since recent findings suggest an important role of the tubular TH protein in the development of tubulointerstitial nephritis (Hoyer \& Seiler Kidney Int 16:279, 1979). Methods: 39 children with previous UTI and renal damage but no recent infection were selected. Sera were analysed for antibodies to TH protein and creatinine levels. Renal parenchymal area was measured on IVP films by planimetry. Results: $80 \%$ of the patients had IgG $\mathrm{TH}$ antibodies below $-2 \mathrm{SD}$ of the reference. Patients with elevated creatinine had significantly lower TH antibodies than those with normal creatinine. Total renal area was correlated to the TH antibody levels $(p<0.002)$. Conclusion: Patients with previous UTI and subnormal IgG anti TH levels are likely to have renal damage. Lower antibodies indicate more extensive damage. 